\title{
Comparative evaluation of bacterial culture and two ELISA techniques for the detection of Renibacterium salmoninarum antigens in salmonid kidney tissues
}

\author{
Eva Jansson $^{1, *}$, Torbjörn Hongslo ${ }^{1}$, Johan Höglund ${ }^{1}$, Olle Ljungberg ${ }^{2}$ \\ ${ }^{1}$ National Veterinary Institute, Box 7073, S-75007 Uppsala, Sweden \\ ${ }^{2}$ Department of Pathology, Faculty of Veterinary Medicine, Swedish University of Agricultural Sciences, Box 7028. \\ S-750 07 Uppsala, Sweden
}

\begin{abstract}
Soluble antigens from Renibacterium salmoninarum (Rs) incorporated into immunostimulating complexes (iscoms) induced polyclonal antibodies directed to the heat-stable, $57 \mathrm{kDa}$ antigen complex of Rs. The antibodies were used in an enzyme-linked immunosorbent assay (ELISA) for the detection of Rs antigens in salmonid kidney samples. The negative-positive threshold value in the ELISA was determined to be 0.10 based on the analyses of 408 samples from rainbow trout Oncorhynchus mykiss, Arctic char Salvelinus alpinus, Baltic salmon Salmo salar, and brown trout Salmo trutta, all negative for Rs by bacterial culture. The Rs organism was isolated on selective kidney disease medium (SKDM) after up to $12 \mathrm{wk}$ of incubation from $45 \%$ of the samples collected from fish farms having enzootic bacterial kidney disease (BKD), and from fish in populations with clinical signs of BKD ( $\mathrm{n}=260$ ). Soluble antigens of Rs were detected with the polyclonal ELISA in $50 \%$ of these samples. In a comparative evaluation of 3 diagnostic techniques (bacterial culture, the polyclonal ELISA described here, and a commercially available ELISA based on monoclonal antibodies), 167 kidney samples were individually analyzed. The results of the diagnostic tests (positive or negative) were identical for $95 \%$ of the examined samples. A higher sensitivity of the polyclonal ELISA when compared with the monoclonal method was indicated in this study.
\end{abstract}

KEY WORDS: Bacterial kıdney disease Diagnostics $\cdot$ ELISA $\cdot$ Renibacterium salmoninarum - Iscom

\section{INTRODUCTION}

Renibacterium salmoninarum (Rs) is the causative agent of bacterial kidney disease (BKD), a chronic systemic infection of salmonid fishes (Fryer \& Sanders 1981) which can be transmitted vertically (Evelyn et al. $1984 \mathrm{a}$, b) as well as horizontally (Bell et al. 1984). As chemotherapy and vaccination have only limited effects, the control of BKD is dependent on sanitary methods and a continuous health monitoring of farmed and feral fish populations.

In Sweden, the first case of BKD was diagnosed in 1985. Since then, the causative agent has been de-

\footnotetext{
·E-mail:eva.jansson@sva.se
}

tected, with different degrees of disease manifestation, from about 50 fish farms, mainly on the east coast. Rainbow trout Oncorhynchus mykiss, the species commonly reared in Swedish fish farming, seems to be more resistant to BKD than Arctic char Salvelinus alpinus and Baltic salmon Salmo salar.

The Rs agent is a slow-growing, Gram-positive short rod that survives and multiplies intracellularly in the host (Young \& Chapman 1978). Confirmatory diagnostic methods used in the control program for clinical BKD in Sweden since 1985 are Gram staining, immunofluorescent antibody staining of smears and the peroxidase-antiperoxidase immunohistochemical technique (Jansson et al. 1991). Fish populations have routinely been tested by bacterial culture to detect car- 
riers (i.e. fish lacking clinical lesions). With culture, Benediktsdóttir et al. (1991) found it necessary to use a prolonged incubation of up to $12 \mathrm{wk}$ in order to avoid false negative results. The long incubation time, however, increases the danger of contamination of agar plates with more rapidly dividing bacteria and fungi, rendering infections by this slow-growing bacterium difficult to detect. At times, agar plates must be discarded prematurely due to overgrowth by contaminating microbes. Furthermore, the lengthy $12 \mathrm{wk}$ incubation necessary before a definite diagnosis can be obtained is unsatisfactory, particularly from an epidemiological point of view. Alternative diagnostic techniques for routine screening purposes which have been developed are based on the use of specific probes for bacterial rRNA or immunological identification of specific bacterial antigens in infected tissues.

A specific probe for the identification of rRNA from Rs was designed and used at the National Veterinary Institute for the detection of BKD in clinical samples by direct filter hybridization. Although this method showed a high specificity for Rs, the sensitivity was lower than that achieved by culture (Mattsson et al. 1993). Development of immunological methods, such as the enzyme-linked immunosorbent assay (ELISA) and Western blot for the detection of antigens of Rs using both monoclonal and polyclonal antibodies have been reported by different authors. These methods offer a higher sensitivity than fluorescent antibody techniques (Hsu et al. 1991, Rockey et al. 1991, Meyers et al. 1993) or cultivation on agar media (Pascho et al. 1987, Griffiths et al. 1991, Gudmundsdottir et al. 1993, Olea et al. 1993).

Previously applied immunological methods have used antibodies against whole cells or soluble antigens of Rs. Antigens from viruses incorporated into socalled immunostimulating complexes (iscoms) by hydrophobic interactions with micelles of the glycoside Quil A (Morein et al. 1984) were demonstrated to be more immunogenic in mice than the antigens alone (Sundqvist et al. 1988). In the present study, we developed a polyclonal ELISA for the detection of Rs antigens in salmonid kidney samples. The capture antibodies used in this ELISA were produced by injecting rabbits with antigens from Rs incorporated into iscoms. The applicability of this ELISA method for detection of Rs in fish populations was evaluated and compared with the cultivation of kidney samples on selective agar using an incubation time of 12 wk. In addition, samples collected from rainbow trout and salmon experimentally challenged by immersion in water contaminated with live Rs were included in the study. A limited number of samples was also tested with a commercially available monoclonal ELISA kit for further comparison.

\section{MATERIALS AND METHODS}

Bacteria. The bacterial strains included in this study are listed in Table 1. Strains of Rs isolated from fish with clinical signs of BKD were grown on charcoal agar, KDM-C agar (Daly \& Stevenson 1985) or on selective kidney disease medium, SKDM agar (Austin et al. 1983), supplemented with $10 \%$ heat-inactivated sheep serum instead of calf serum, at $15^{\circ} \mathrm{C}$. All other bacteria were grown on horse blood $(5 \%)$ agar at $20^{\circ} \mathrm{C}$ or $37^{\circ} \mathrm{C}$.

Polyclonal antibody preparations. Antigens for iscom preparation were prepared from Rs strain 4/86 (Table 1), cultivated on KDM-C agar for $15 \mathrm{~d}$ as follows. Bacteria were suspended in peptone-saline ( $0.1 \%$ peptone, Difco laboratories, Detroit, MI, USA) and centrifuged at $2500 \times g$ for $20 \mathrm{~min}$. The pellet was resuspended in distilled water containing $2 \%$ of the detergent MEGA 10 (Hildreth 1982, Hanatani et al. 1984) and incubated at $37^{\circ} \mathrm{C}$ with mild agitation for $1 \mathrm{~h}$. The suspension was sonicated and centrifuged (3000 $\times$ g) for $10 \mathrm{~min}$. The protein content of the supernatant was quantified by the method of Bradford (1976), and iscoms were prepared according to the principles of Morein et al. (1984). Briefly, the supernatant was mixed with 1-3-phosphatidyl choline 1,2-dipalmitoyl, cholesterol ( $1 \%$ of each) and the glycoside Quil A $(0.2 \%)$. The mixture was dialysed against phosphatebuffered saline, pH 7.2 (PBS) for $5 \mathrm{~h}$ at room temperature and then at $4^{\circ} \mathrm{C}$. Antigens were also extracted from the bacterium by washing in distilled water (pH 5.5) according to the hemagglutinin water-extraction method described by Daly (1989).

Rabbits were injected intramuscularly with $300 \mu \mathrm{l}$ of the iscom preparation $(21 \mathrm{\mu g}$ protein) or with $50 \mathrm{\mu g}$ of the extracted hemagglutinin in Freund's complete adjuvant and booster-injected 3 and 5 wk later, in the same manner except that Freund's incomplete adjuvant was used for the booster injections with the hemagglutinin. Blood was collected after an additional $2 \mathrm{wk}$ and 1 and 2 wk thereafter. Repeated booster injections were administered every 10 th week. Blood samples collected before the first immunization were used as a control. Rabbit IgG was purified from serum on a Protein G column (Pierce, Rockford, IL, USA), dialysed against PBS and distilled water and then freeze-dried. The effectiveness of the resulting rabbit IgGs as capture antibodies in ELISA was compared by the Mann-Whitney Wilcoxon test (Altman 1991).

SDS-PAGE and Western-immunoblotting. The Rs strain $4 / 86$, was inoculated into a semidefined medium (Embley et al. 1982) and incubated with agitation at $17^{\circ} \mathrm{C}$ for $4 \mathrm{wk}$. Bacterial growth was harvested, diluted, and treated as described for the preparation of samples for the polyclonal ELISA. The supernatant was boiled 
Table 1. Bacterial strains isolated from fish and other sources that were tested by the polyclonal ELISA (rabbit anti-Rs iscoms as capture antibodies). CCUG: Culture collection of the University of Göteborg, Sweden; NVI-N: National Veterinary Institute, Oslo, Norway; NVI-S: National Veterinary Institute, Uppsala, Sweden

\begin{tabular}{|c|c|c|c|c|}
\hline Strain & Isolated from & Source & Species & ELISA result \\
\hline $4 / 86$ & Oncorhynchus mykiss & NVI-S & Renibacterium salmoninarum & + \\
\hline 41837 & Salmo salar & NVI-N & Renibacterium salmoninarum & + \\
\hline $2300 / 85$ & Oncorhynchus myklss & NVI-S & Renibacterium salmoninarum & + \\
\hline $131869 / 85$ & Oncorhynchus mykiss & NVI-S & Renibacterium salmoninarum & + \\
\hline $250 / 86$ & Oncorhynchus mykiss & NVI-S & Renibacterium salmoninarum & + \\
\hline $141 / 87$ & Salmo salar & NVI-S & Renibacterium salmoninarum & + \\
\hline $246 / 87$ & Oncorhynchus mykiss & NVI-S & Renibacterium salmoninarum & + \\
\hline $124 / 88$ & Oncorhynchus mykiss & NVI-S & Renibacterium salmoninarum & + \\
\hline $138 / 3 / 88$ & Oncorhynchus mykiss & NVI-S & Renibacterium salmoninarum & + \\
\hline $138 / 6 / 88$ & Oncorhynchus mykiss & NVI-S & Renibacterium salmoninarum & + \\
\hline $002 / 1 / 92$ & Salvelinus alpinus & NVI-S & Renibacterium salmoninarum & + \\
\hline $002 / 20 / 92$ & Salvelinus alpinus & NVI-S & Renibacterium salmoninarum & + \\
\hline $15 / 67 / 92$ & Salvelinus alpinus & NVI-S & Renibacterium salmoninarum & + \\
\hline $1129 / 2 / 90$ & Salvelinus alpinus & NVI-S & Aeromonas hydrophila & - \\
\hline $000 / 11 / 92$ & Salmo salar & NVI-S & Aeromonas salmonicida ssp. achromogenes & - \\
\hline CCUG 581 & Type strain & CCUG & Arthrobacter globiformis & + \\
\hline CCUG 17757 & Air & CCUG & Arthrobacter oxydans & - \\
\hline $\mathrm{B} 2892 / 83$ & Goat & NVI-S & Corynebacterium pseudotuberculosis & - \\
\hline CCUG 1638 & Human faeces & CCUG & Edwardisiella tarda & - \\
\hline CCUG 19916 & Type strain & CCUG & Streptococcus faecalis & - \\
\hline $1194 / 2 / 92$ & Oncorhynchus mykiss & NVI-S & Vibrio anguillarum serotype 1 & - \\
\hline $261 / 87$ & Salmo trutta & NVI-S & Yersinia ruckeri serotype 2 & - \\
\hline $1185 / 8 / 92$ & Oncorhynchus mykiss & NVI-S & Yeast & - \\
\hline
\end{tabular}

for 5 min in a Tris-HCl buffer, $\mathrm{pH} 6.8$, containing $10 \%$ $(\mathrm{w} / \mathrm{v})$ sodium dodecyl sulphate (SDS) and $50 \mathrm{mM}$ dithiothreitol. The proteins were analysed by polyacrylamide-gel electrophoresis in the presence of SDS in $12 \%$ polyacrylamide (Mini-Protean II System, Bio Rad). Polypeptide bands were visualized with $0.1 \%$ Coomassie blue R-250 solution. Western-immunoblotting was performed to detect antibodies to the different proteins in the supernatant by first separating $25 \mu \mathrm{g}$ of sample and $5 \mathrm{\mu g}$ of BioRad standard in a $4 \%$ SDS stacking gel and in a $12 \%$ resolving gel at $200 \mathrm{~V}$ for $45 \mathrm{~min}$. Proteins were transferred to a nitrocellulose (NC) filter for $1.3 \mathrm{~h}$ at $70 \mathrm{~V}$. The filter was blocked with $5 \%$ milk powder (Semper, Stockholm, Sweden) in Tris$\mathrm{NaCl}$ buffer, $\mathrm{pH} 7.5$ (TBS) for $1 \mathrm{~h}$ and then washed with TBS containing $0.5 \%$ Tween-20 (TTBS). This was followed by a $2 \mathrm{~h}$ incubation with the prepared rabbit IgG, diluted $1: 50$ in TTBS containing $1 \%$ milk (ABbuffer). The incubated NC filters were washed twice with TTBS and then incubated again for $2 \mathrm{~h}$ in peroxidase-conjugated swine anti-rabbit IgG (Dako A/S) diluted 1:500 in AB-buffer. They were then washed in 2 changes of TTBS and 1 change of TBS. Finally, the reaction was developed with 2,3-diamino benzidinetetrahydrochloride (Sigma, St. Louis, MO, USA) in $50 \mathrm{mM}$ Tris- $\mathrm{HCl}, \mathrm{pH} 7.6$ with $0.5 \% \mathrm{H}_{2} \mathrm{O}_{2}$.

Experimental fish. Baltic salmon (2-yr-old) at an average weight of $35 \mathrm{~g}$ and rainbow trout (1-yr-old) at an average weight of $32 \mathrm{~g}$ were successively acclimatized to a temperature of $9 \pm 1^{\circ} \mathrm{C}$ in 250 l tanks supplied with continously flowing well water and were fed commercial trout dry food (Dansk Örredfoder A/S, ECOlife 17. Brande, Denmark). Fish originated from a local fish farm, regularly health monitored as part of the Swedish Fish Health Control Programme, and had no history of BKD. Fish were challenged by immersion in oxygenated water containing $\mathrm{Rs}$ bacteria (strain $15 / 67 / 92 ; 1 \times 10^{8}$ colony forming units $\mathrm{ml}^{-1}$ ). The fish were observed daily and dead fish collected. Surviving fish were killed by an overdose of MS 222 (Sandoz, Ltd, Basle, Switzerland; $0.75 \mathrm{ml} \mathrm{l}^{-1}$ ) and sampled 4 and 8 wk post-infection.

Sampling procedures. A total of 733 samples came from farmed and feral fish (mainly Baltic salmon Salmo salar) and included both 1- and 2-yr-olds as well as broodstock: 304 samples originated from rainbow trout (64 of these were experimentally challenged as described above), 229 samples from Arctic char, 58 from Baltic salmon (including 45 experimentally challenged as above), and 42 from brown trout. All fish were examined for gross clinical signs of BKD, and kidney samples were taken aseptically into sterile bags for bacterial cultivation and for ELISA, mainly at the fish farms. For the comparision between cultivation, polyclonal ELISA, and the monoclonal ELISA kit, kidney samples were divided into 6 pieces and 2 of 
these were randomly placed in each of 3 bags, in order to compensate for a possible nonrandom distribution of bacteria or bacterial antigens in sampled kidney tissue.

Bacterial culture. The kidney samples were mechanically homogenized (Stomacher Lab Blender 80, Seward Laboratory, London, UK) in peptone-saline, approximately $10 \mathrm{ml} \mathrm{g}^{-1}$ of tissue, and centrifuged at $2500 \times \mathrm{g}$ for $20 \mathrm{~min}$ at $4^{\circ} \mathrm{C}$. Supernatants were discarded and the pellets were resuspended in peptonesaline at a $1: 1$ ratio $(w / v)$. Ten $\mu$ lof the homogenate was spread on SKDM agar, horse blood (5\%) agar, and KDM-C agar. SKDM and KDM-C agar plates were incubated in plastic bags at $15^{\circ} \mathrm{C}$ and examined weekly. SKDM plates were incubated for up to $12 \mathrm{wk}$. The long incubation time for SKDM was necessary since visible colonies of Rs appeared between the 6th and 11 th week in several low-grade infected samples. Benediktsdóttir et al. (1991) found the highest prevalence of positive samples during the 6th and 9th week of incubation. In order to minimize problems with samples contaminated with bacteria or fungi and thus optimize the cultivation method, each kidney sample was spread onto the whole surface of an agar plate. Blood agar plates were incubated at $20^{\circ} \mathrm{C}$ and examined after $4 \mathrm{~d}$. Pure culture of isolated bacterial fish pathogens were identified by conventional methods including biochemical and serological tests. Growth of Rs was confirmed by Gram staining and immunofluorescence (monoclonal antibody against Rs, Micrologix International Limited, Sidney, BC, Canada) on typical colonies from SKDM agar. Strains of Rs were further verified by catalase and oxidase reactions and finally with APIzym (bioMérieux, Marcy-l'Étoile, France; Austin \& Austin 1987). Samples were processed immediately at the laboratory, with the exception of 52 samples (from brown trout, rainbow trout, and Baltic salmon) which were kept frozen at $-20^{\circ} \mathrm{C}$ for up to 1 mo prior to cultivation.

Sample preparation for polyclonal ELISA. Samples for the polyclonal ELISA were prepared according to the method of Gudmundsdóttir et al. (1993):

Bacterial samples (Table 1): The bacteria were diluted to an optical density (OD) of 1.0 at $660 \mathrm{~nm}$ in PBS, and $25 \mu \mathrm{l}$ of the solvent HemoDe (terpene and butylated hydroxy anisole, Fisher Scientific, Pittsburg, PA, USA) was added for each $\mathrm{ml}$ of suspension. The samples were carefully mixed and heated to $98 \pm 2{ }^{\circ} \mathrm{C}$ in an autoclave for $15 \mathrm{~min}$. After centrifugation at $2500 \mathrm{~g}$ for $20 \mathrm{~min}$, the aqueous phase was collected and used in the ELISA.

Kidney samples: Homogenates were prepared with 1 part kidney, 3 parts PBS, and 25 ll HemoDe per ml homogenate in a stomacher. The samples were heated and treated as described for the bacterial samples. Kid- ney samples were analysed directly by the ELISA or were frozen at $-20^{\circ} \mathrm{C}$ for later assay.

Polyclonal ELISA. Coating and blocking: Microtiter plates (Nunc 4-42404, Roskilde, Denmark) were coated overnight at $4{ }^{\circ} \mathrm{C}$ with rabbit IgG $\left(10 \mu \mathrm{g} \mathrm{m}^{-1}\right)$ prepared against Rs iscoms diluted in $0.05 \mathrm{M}$ carbonate buffer, $\mathrm{pH} 9.6\left(200 \mu \mathrm{l}_{\mathrm{well}}{ }^{-1}\right)$. Initially, plates were also coated with rabbit IgG prepared against Rs hemagglutinin (HA) and with normal rabbit Ig at the same concentration and in the same manner as described above. Afterwards, 4 washes were carried out with saline $10.9 \%$ $\mathrm{NaCl}_{i} 0.001 \mathrm{M}$ PBS) containing $0.5 \%$ Tween 20. All wells were blocked with $1 \%$ bovine serum albumin (Sigma a-4503, St. Louis, MO, USA; $200 \mu l$ well $^{-1}$ ) in distilled water for at least $30 \mathrm{~min}$ at room temperature (RT) before the samples were added.

Samples: A volume of $50 \mu \mathrm{l}$ PBS containing $0.5 \%$ Tween 20 (PBS-Tween) was added to all wells, followed by addition of $50 \mu$ l of supernatant from each prepared sample to each of 2 wells. A negative control prepared from a pool of kidney samples from 20 Rsnegative rainbow trout (checked by bacterial cultivation) was tested in 4 wells on every microtiter plate. Dilutions of a HemoDe-treated Rs suspension were tested as positive controls (2 antigen concentrations, PC 1 and PC 2). PBS-Tween was added to the first row of every plate and the resulting background $O D$ value was subtracted from all sample values. The microtiter plates were incubated at RT for $2 \mathrm{~h}$.

Conjugate: Affinity-purified, peroxidase-labelled goat anti-Renibacterium salmoninarum (Kirkegaard \& Perry Laboratories Inc., Gaithersburg, MD, USA) diluted in PBS-Tween to a concentration of $0.2 \mu \mathrm{g} \mathrm{ml}^{-1}$ was added to all wells $\left(100 \mu l\right.$ well $\left.l^{-1}\right)$ and incubated at RT for $1 \mathrm{~h}$.

Substrate: The enzyme reaction was visualized using tetramethylbenzidine (Kebo, Stockholm, Sweden) at a concentration of $0.1 \mathrm{mg} \mathrm{m} \mathrm{m}^{-1}$ in $0.1 \mathrm{M}$ acetate buffer, pH 6.0 , containing $\mathrm{H}_{2} \mathrm{O}_{2}(0.006 \%)$. The reaction was stopped after 10 min with $1 \mathrm{M} \mathrm{H}_{2} \mathrm{SO}_{4}$ and the $\mathrm{OD}$ was measured by spectrophotometer at $450 \mathrm{~nm}$

Negative-positive threshold: The negative-positive threshold of the ELISA was defined as the mean OD values plus 3 standard deviations of samples from clinically healthy fish, tested by bacterial culture to be negative.

Control of false positive reactions: All samples exceeding the negative-positive threshold value in the ELISA were checked for false positive reactions by repeating the ELISA: Microtiter plates were coated with the same rabbit IgG prepared against Rs iscoms but also with normal rabbit $\operatorname{IgG}\left(10 \mu \mathrm{g} \mathrm{ml}^{-1}\right.$. Dako AVS, Glostrup, Denmark), 1 well of each for every sample. The ELISA was subsequently performed as previously described. 
Interassay correction: Interassay variations in the ELISA were corrected by a method modified from Pascho et al. (1987): All values were multiplied by a correction factor, $1-A$, for each microtiter plate tested. $A$ is defined according to the following formula:

$$
A=\frac{1}{2}\left[\frac{\mathrm{PC} 1_{i}-\mathrm{PC}_{1}}{\mathrm{PC} 1_{i}}+\frac{\mathrm{PC} 2_{i}-\mathrm{PC} 2_{x}}{\mathrm{PC} 2_{i}}\right]
$$

where $\mathrm{PC} 1_{i}=$ the absorbance values of positive control 1 (the mean value of duplicates) at each plate; $\mathrm{PC} 2_{i}=$ the absorbance values of positive control 2 (the mean value of duplicates) at each plate; $\mathrm{PC} 1_{x}=$ the mean absorbance values of positive control 1 in all plates tested, $P C 2_{x}=$ the mean absorbance values of positive control 2 in all plates tested.

K-Dtect ELISA. A commercially available monoclonal ELISA kit marketed as K-Dtect (DiagXotics Wilton, CT, USA) was used in accordance with the manufacturer's instructions. Briefly, kidneys were diluted in sample dilution buffer (SDB; $1 \mathrm{~g}$ kidney : $1 \mathrm{ml}$ SDB), homogenized, and centrifuged. The supernatants were added to duplicate wells of a microtiter plate that had been coated with monoclonal antibodies against a soluble $57 \mathrm{kDa}$ antigen of Rs (p57). The plate with samples, positive controls with varying concentrations of p57 antigen, and negative controls, was incubated for $1 \mathrm{~h}$ at RT before the plate was washed to remove unbound material. A biotinylated monoclonal antibody directed to a different epitope of p57 antigen was then added to the wells for a $1 \mathrm{~h}$ incubation at RT. After washing, streptavidin linked to horseradish peroxidase was added for incubation for $30 \mathrm{~min}$. Finally, the plate was washed, the chromogen ABTS and $\mathrm{H}_{2} \mathrm{O}_{2}$ were added, and the OD was measured with a spectrophotometer. The washing solution and SDB were diluted prior to use. All other working solutions of reagents were included in the test kit.

\section{RESULTS}

\section{Specificity of rabbit IgG}

The iscom-induced rabbit anti-Renibacterium salmoninarum IgG was superior as capture antibodies in the ELISA when compared with the HA-induced antibodies (Table 2). Differences in OD values, using the 2 antibody preparations for capture in samples collected from experimentally challenged rainbow trout and salmon, were found to be significant by the MannWhitney Wilcoxon test $(\mathrm{p}=0.01)$.

No cross reactivities of the iscom-induced rabbit IgG with other fish-pathogenic bacterial strains were found using the polyclonal ELISA. All strains of Rs (13 different isolates) gave strong extinction values. Among the
Table 2. (a) Serial dilutions of Rs (strain 15/67/92) in peptonesaline tested by ELISA. Microtiterplates were coated with Ig from non-immunized and immunized rabbits. (b) Efficiency of antibodies from rabbits immunized with Rs iscoms was compared with the Rs HA-induced antibodies as capture antibodies in the ELISA. Microtiterplates were coated with IgG at a dilution of $10 \mathrm{\mu g} \mathrm{ml}^{-1}$ Samples were collected from fish experimentally challenged by immersion and from fish in the control group (non-challenged). OD values expressed as the mean value $\pm \mathrm{SD}$. (-: no growth of Rs; + : sparse growth of Rs: +++ : ample growth of Rs)

\begin{tabular}{|c|c|c|c|}
\hline \\
\hline $\begin{array}{l}\text { No. of Rs } \\
\text { in sample } \\
\text { (viable count) }\end{array}$ & \multicolumn{3}{|c|}{$\begin{array}{l}\text { OD values in ELISA (450 nm) after } \\
\text { coating with Ig from non-immunized } \\
\text { and immunized rabbits }\end{array}$} \\
\hline & $\begin{array}{l}\text { Non-immunized } \\
\text { rabbit }\end{array}$ & $\begin{array}{c}\text { Rabbit } \\
\text { anti-Rs HA }\end{array}$ & $\begin{array}{c}\text { Rabbit anti-Rs } \\
\text { iscoms }\end{array}$ \\
\hline $1 \times 10^{7}$ & 0.071 & 2.106 & 2.249 \\
\hline $1 \times 10^{6}$ & 0.034 & 0.763 & 1.720 \\
\hline $1 \times 10^{5}$ & 0.044 & 0.093 & 0.377 \\
\hline $1 \times 10^{4}$ & 0.024 & 0.021 & 0.058 \\
\hline $1 \times 10^{3}$ & 0.026 & 0.022 & 0.036 \\
\hline \multicolumn{4}{|l|}{ (b) } \\
\hline \multirow[t]{2}{*}{ Group } & \multirow[t]{2}{*}{$\begin{array}{l}\text { Cultivation } \\
\text { (SKDM) }\end{array}$} & \multicolumn{2}{|c|}{$\begin{array}{l}\text { OD values in ELISA } \\
\text { (450 } \mathrm{nm} \text { ) after coating with } \\
\text { IgG from immunized rabbits }\end{array}$} \\
\hline & & $\begin{array}{l}\text { Rabbit } \\
\text { anti-Rs HA }\end{array}$ & $\begin{array}{l}\text { Rabbit anti-Rs } \\
\quad \text { iscoms }\end{array}$ \\
\hline $\begin{array}{l}\text { Control } \\
(n=21)\end{array}$ & - & $0.002 \pm 0.008$ & $0.006 \pm 0.010$ \\
\hline $\begin{array}{l}\text { Challenged } \\
(n=14)\end{array}$ & $-1+$ & $0.009 \pm 0.034$ & $0.210 \pm 0.180$ \\
\hline $\begin{array}{l}\text { Challenged } \\
(n=14)\end{array}$ & +++ & $1.151 \pm 0.485$ & $1.551 \pm 0.335$ \\
\hline
\end{tabular}

non-fish pathogens tested, a positive OD value was obtained with a bacterial preparation of Arthrobacter globiformis (Table 1). In Western blot, major immunoreactive bands of the Rs antigen preparation were detected with the rabbit anti-Renibacterium salmoninarum iscom IgG near $57 \mathrm{kDa}$, as well as 2 immunoreactive bands of lower molecular mass. An identical profile was obtained with the polyclonal antibodies produced after immunization with the water-extracted HA of the bacterium (Fig, 1).

\section{Polyclonal ELISA standardization}

Based on the OD values of kidney samples $(n=408)$ from rainbow trout, Arctic char, Baltic salmon, and brown trout collected from fish negative for Rs by bacterial culture, the negative-positive threshold value in the polyclonal ELISA was determined to be 0.10. All 


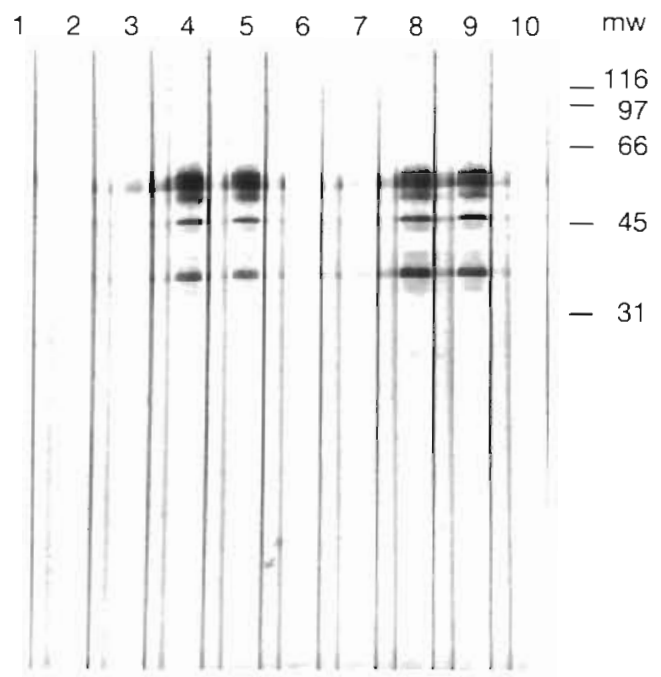

Fig. 1. Western immunoblotting of Renibacterium salmoninarum antigens. Lanes were incubated with: $\mathrm{AB}$-buffer ( 1 and 6); rabbit serum (control) ( 2 and 10 ); IgG fractions from the rabbits prior to immunization ( 3 and 7 ); serum from a rabbit immunized with $R$. salmoninarum-soluble antigens arranged into iscoms ( $\mathrm{Rb}$ anti-Rs iscoms) (4); the IgG fraction of $\mathrm{Rb}$ antiRs iscoms (5); serum from a rabbit immunized with waterextracted hemagglutinin of $R$. salmoninarum (Rb anti-Rs $\mathrm{HA}$ ) (8); the IgG fraction of Rb anti-Rs HA (9). The column ' $m w^{\prime}$ shows molecular weight standards in $\mathrm{kDa}$

kidney samples originated from fish farms or fish populations considered to be free from Rs infection. Initially, 3 dilutions (i.e. undiluted homogenate, 1:2, and 1:4) of kidney samples were tested, both with the rabbit anti-Renibacterium salmoninarum IgG and with normal rabbit IgG, to determine optimum background OD levels. Acceptably low background OD values

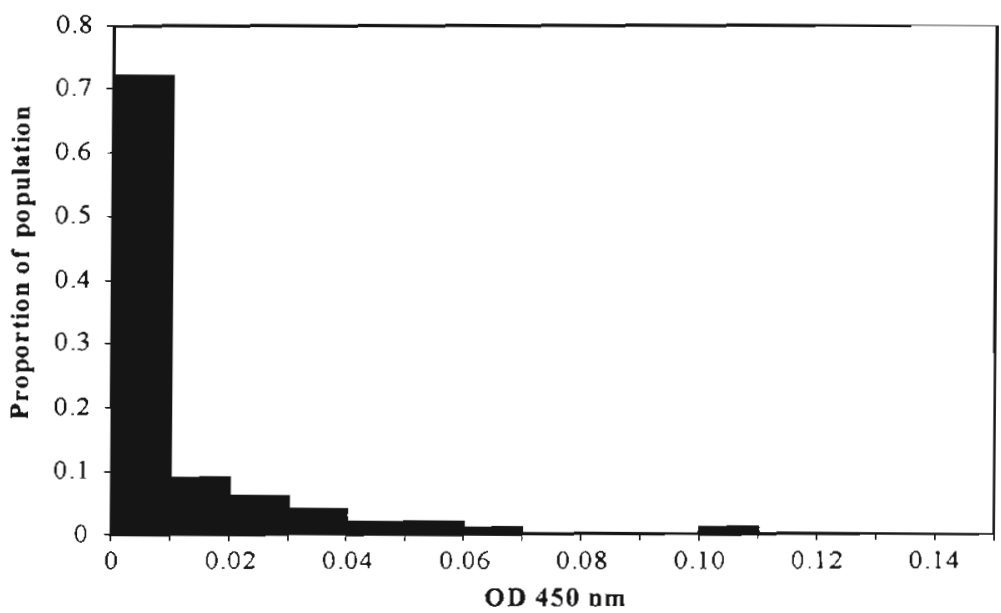

Fig. 2. Observed distribution of polyclonal. ELISA optical density (OD) values from rainbow trout Oncorhynchus mykiss, Arctic char Salvelinus alpinus, Baltic salmon Salmo salar, and brown trout Salmo trutta, which were diagnosed as negative by cultivation (no live Rs were detected in the samples; $n=408$ )
Table 3. (a) Detection of Rs in salmonid kidney samples from asymptomatic fish by isolation on selective agar (SKDM) and by polyclonal ELISA ( $\mathrm{n}=408$ ). (b) Detection of Rs in salmonid kidney samples by isolation on selective agar (SKDM) and by polyclonal ELISA $(n=325)$. Samples were collected from fish at fish farms where enzootic BKD had previously been detected by cultivation or from fish populations with clinical signs of Rs-infection

\begin{tabular}{|c|c|c|c|}
\hline \multirow[t]{2}{*}{ (a) } & & \multicolumn{2}{|c|}{$\begin{array}{c}\text { Polyclonal } \\
\text { ELISA }\end{array}$} \\
\hline & & Pos & $\mathrm{Neg}$ \\
\hline \multirow{3}{*}{$\begin{array}{l}\text { Cultivation } \\
\text { (SKDM) }\end{array}$} & OPOS & 0 & 0 \\
\hline & 368 Rs not detected & 1 & 367 \\
\hline & 40 Contaminated ${ }^{a}$ & 0 & 40 \\
\hline
\end{tabular}

\begin{tabular}{|c|c|c|c|}
\hline \multirow[t]{2}{*}{ (b) } & & \multicolumn{2}{|c|}{$\begin{array}{l}\text { Polyclonal } \\
\text { ELISA }\end{array}$} \\
\hline & & Pos & Neg \\
\hline \multirow{3}{*}{$\begin{array}{l}\text { Cultivation } \\
\text { (SKDM) }\end{array}$} & 118 Pos & 113 & 5 \\
\hline & 142 Rs not detected & 17 & 125 \\
\hline & 65 Contaminated ${ }^{\mathrm{a}}$ & 24 & 41 \\
\hline
\end{tabular}

were observed at the 1:2 dilution of the prepared sample. The use of 4 washings between every incubation step in the ELISA instead of 3 washings, as was used initially, further lowered the background OD value. In these samples, when only 3 washings were used, the negative-positive threshold value was set at 0.14 (74 samples collected from farms with clinical BKD and 77 samples from populations considered to be free of Rs). A Tween-20 content of $0.5 \%$ was used throughout in this study. Although the ELISA procedures were standardized, day-to-day variations occurred, especially in samples showing high $O D$ values. To compensate for this variation, all values (exept values from the experimentally challenged fish) were corrected by the modified Pascho et al. (1987) statistic. The mean of the negative control samples was reduced from 0.019 to 0.015 by this correction, but the status of positive or negative values remained unchanged. Observed distributions of $O D$ values from samples classified as negative by bacterial culture are summarized in 


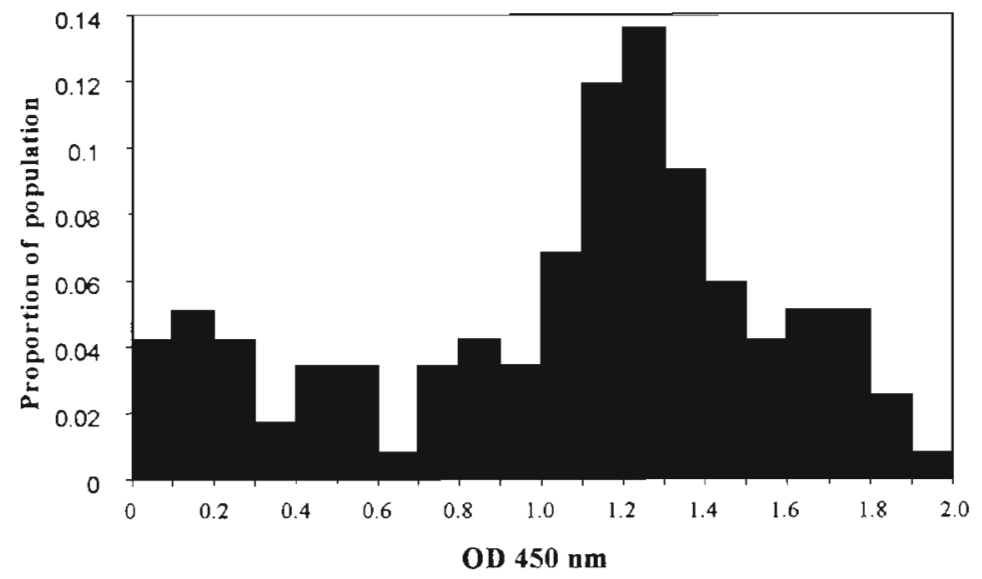

Fig. 3. Observed distribution of polyclonal ELISA optical density (OD) values from rainbow trout Oncorhynchus mykiss, Arctic char Salvelinus alpinus, and Baltic salmon Salmo salar, which were diagnosed as positive by cultivation $(\mathrm{n}=118)$

Fig. 2. OD values exceeding 0.10 in Fig. 2 were from samples tested initially in this study when the threshold value was set at 0.14 . A high proportion of negative samples gave OD values below 0.000 . These values have all been corrected to 0.000 in Fig. 2 .

\section{Bacterial cultivation and the polyclonal ELISA}

The results obtained with the above techniques are summarized in Table 3. The Rs organism was isolated on SKDM from 118 kidney samples (45\%) from fish collected from fish farms where BKD had been diagnosed earlier or from experimentally challenged fish. Analysis of the same kidneys by ELISA classified 130 samples $(50 \%)$ as positive for Rs. Observed distributions of OD values from samples classified as positive by bacterial culture are summarized in Fig. 3. Sparse growth of Rs was detected on the agar from 5 samples determined to be negative by ELISA. In 24 of 41 samples positive only by ELISA, the result of SKDM could not be interpreted, as the agar was covered with contaminating bacteria and fungi. The SKDM agar plates were contaminated in 40 samples collected from fish without any suspicion of infection (either clinically or historically); all of these samples proved negative in the ELISA. One fish out of the remaining 368 exceeded the threshold value. Kidney samples from fish naturally infected with Gram-negative pathogenic bacteria (Aeromonas salmonicida ssp. salmonicida, Yersinia ruckeri, and Flavobacterium psychrophilum) in this study tested negative in the ELISA. On the basis of the results in Table $3 a$, the specificity of the polyclonal ELISA method was set at 99.7\%. According to Table $3 \mathrm{~b}$, the sensitivity was calculated to be $95.8 \%$ when compared with cultivation. However, several samples only showed positive by ELISA. ELISA values of samples with an overgrowth of contaminating microbes on SKDM were excluded in the calculations.

\section{Comparison of SKDM, polyclonal ELISA, and K-Dtect ELISA}

Cultivation of Rs on SKDM was compared with both the ELISA method described here and a commercially available ELISA method for samples from 175 fishes (Table 4). It was not possible to interpret 8 samples, with identical classification by the 2 ELISA methods in cultivation because of contamination of the SKDM agar. An agreement between all 3 methods occurred in 159 of the remaining samples (41 positive and 118 negative). Four kidneys, negative in K-Dtect, were positive with both cultivation and the polyclonal ELISA, and an additional 2 kidneys were positive only with the polyclonal ELISA. Rs was not cultivable from 1 sample showing positive according to both the ELISA methods whereas one sample was positive only by cultivation.

\section{DISCUSSION}

Previous studies of immunostimulating complexes (iscoms), especially those containing antigens from viruses, have demonstrated the advantage of this antigen preparation over more traditional preparations (Morein et al. 1984, Lövgren et al. 1987). The ability of the iscoms to stimulate immunogenicity depends

Table 4. Detection of Renibacterium salmoninarum in salmonid kidney samples $(\mathrm{n}=175)$ by cultivation on selective agar (SKDM) and by 2 ELISA methods (polyclonal ELISA and K-Dtect)

\begin{tabular}{|c|c|c|c|c|c|}
\hline & & \multicolumn{2}{|c|}{$\begin{array}{c}\text { Polyclonal } \\
\text { ELISA }\end{array}$} & \multicolumn{2}{|c|}{ K-Dtect } \\
\hline & & Pos & Neg & Pos & Neg \\
\hline \multirow{3}{*}{$\begin{array}{l}\text { Cultivation } \\
\text { (SKDM) }\end{array}$} & 46 Pos & 45 & 1 & 41 & 5 \\
\hline & 121 Rs not detected & 3 & 118 & 1 & 120 \\
\hline & 8 Contaminated & 3 & 5 & 3 & 5 \\
\hline
\end{tabular}


mainly on a favorable presentation of the antigens, but is also dependent on the iscoms' function as an adjuvant (Dalsgaard 1978). Iscoms consist of Quil A, a glycoside which forms micelles which build complexes with cholesterol, into which antigens are incorporated by hydrophobic interactions. Several authors have described the hydrophobic nature of the cell surface of Rs (Daly \& Stevenson 1987, Bruno 1988), and a capsule structure was recently demonstrated (Dubreuil et al. 1990) which may contain valuable specific diagnostic antigen(s).

In the present study, we used solubilized antigens extracted by a mild detergent for incorporation into iscom structures visible in electron micrographs (data not shown). Rabbits that were immunized with this immunogen produced antibodies with a similar profile in Western blot to those produced towards waterextracted HA antigens. The iscom-generated antibodies reacted primarily with the antigen $F$ (Getchell et al. 1985), which in earlier studies has been described as a heat-stable antigen of $57 \mathrm{kDa}$, but also as having 2 lower molecular mass antigens that may be degradation products of antigen F (Griffiths \& Lynch 1991). Antibodies produced with the iscom immunogen reacted with 13 geographically diverse isolates of Rs and were chosen for the ELISA because they were found in initial tests to be more effective as capture antibodies than the HA-induced antibodies. No cross reactivity against other fish-pathogenic bacteria has been detected. Cross reaction was detected against Arthrobacter globiformis, a bacterium earlier described as related to Rs (Stackebrandt et al. 1988). This bacterium is easily cultivated on blood agar, but has not been reported to have been isolated from fish tissues.

On the basis of analyses of 408 samples from rainbow trout, Arctic char, Baltic salmon, and brown trout classified as negative for $\mathrm{BKD}$, the negative-positive threshold value in the present ELISA was determined to be 0.10 . In accordance with earlier studies, no species-specific differences in OD values were observed among the negative samples (Gudmundsdóttir et al. 1993, Meyers et al. 1993). One sample did exceed the threshold value in this group, but no growth of bacteria was detected when the kidney sample was cultivated on blood agar or KDM-C. Therefore, it seems unlikely that other bacteria were cross-reacting. One single fish sampled in the same population on the same occasion showed clinical indications of bacterial infection (ascitic fluid in the peritoneum, petechial hemorrhages of the heart, and pale liver). However, it was not possible to verify $\mathrm{BKD}$ by the immunofluorescent antibody technique or cultivation. The negative result of cultivation from the ELISA-positive fish might be explained by a higher sensitivity of the ELISA method, by an unequal distribution of bacteria, or the presence of bacterial antigens alone in the sampled kidney tissue.

The sensitivity of the present ELISA method was compared with that for cultivation on SKDM of kidney samples collected from fish farms classified as Rsinfected or with fish showing clinical indications of BKD as well as from fish experimentally challenged with Rs by immersion. The Rs organism was isolated on SKDM from 68 out of 69 fish with macroscopic signs of BKD (swollen, greyish kidney). All of these samples were also classified as positive by the ELISA. Among samples collected from fish with weak or no clinical indications of $B K D, 44$ samples were shown positive by both methods. A discrepancy between the 2 methods was seen in 22 samples (Table $3 b$ ), which might again be caused by an unequal distribution of low numbers of bacteria or the presence of bacterial antigens alone in the kidneys. Twelve more cases were positive according to the ELISA as compared with the SKDM performed under optimal conditions (contaminated agar plates excluded). Therefore it can be concluded that the present ELISA method is comparable with or has even greater sensitivity than cultivation, which is in accordance with earlier studies (Pascho et al. 1987, Griffiths et al. 1991, Gudmundsdóttir et al. 1993). From a practical point of view, the ELISA method also appears more reliable than culture as the latter is susceptible to contamination problems when sampling is carried out in the field.

Results produced by all 3 methods were identical in $95 \%$ for 167 kidney samples tested by cultivation on SKDM, polyclonal ELISA, and K-Dtect. Six samples from a fish farm having enzootic BKD were negative by the K-Dtect but were positive by polyclonal ELISA. Four of these samples were also positive on SKDM. These data indicated a higher sensitivity of the polyclonal ELISA method when compared with the KDtect. This is not surprising, because several different epitopes for capture are possible using polyclonal antibodies that are not recognized by monoclonals. The existence of antigenic heterogeneity of Rs surface proteins has previously been indicated by immunogenic analysis (Bandin et al. 1992). The p57 antigen is released into fish tissues during infection (Turaga et al. 1987, Rockey et al. 1991), which may increase the accessibility of antigens for the capture antibodies. This may explain the higher sensitivity reported with the use of ELISA than with the use of cultivation on agar medium. The detection limit of polyclonal ELISA determined from serial dilutions of a washed broth culture of Rs added to homogenized kidney material, was $9 \times 10^{6}$ bacteria $g^{-1}$ of kidney, in accordance with the results of Bandin et al. (1996). In naturally infected fish, however, kidneys estimated to contain $10^{3} \mathrm{Rs} \mathrm{g}^{-1}$ of kidney were found positive by polyclonal ELISA (data 
not shown). Testing of more Rs-negative samples will probably lower our threshold level because higher background OD values obtained in the initial part of this study were included in the negative-positive threshald value of 0.10 . A consequence of a reduction of this value would, of course, be a lower detection limit.

In conclusion, we found polyclonal ELISA, using the iscom-induced rabbit anti-Renibacterium salmoninarum IgG for capture, to be useful for routine screening for Rs in fish populations in the Swedish Fish Health Control Programme. The sensitivity of the method was comparable with and possibly greater than that of cultivation under optimal conditions. Further, ELISA was more convenient for the screening of wild brood fish.

Acknowledgements. We thank Ulf-Peter Wichardt, Anders Alfjorden and Erik Törnqvist from The Swedish Fish Health Control Programme for their help in the sample collection and Ulla Johansson and Suzanne Martelius-Walter for their skillful help with bacterial laboratory work. We also thank Karin Lövgren for her invaluable help with the iscom preparations and for reviewing the manuscript, Meg Thorburn for valuable discussions, and, finally, Carina Johansson and Camilla Öberg for help in the preparation of this manuscript. This work was supported by the Swedish Council for Forestry and Agricultural Research.

\section{LITERATURE CITED}

Altman DG (1991) Comparing groups-continuous data. In: Practical statistics for medical research. Chapman \& Hall, London, p 179-228

Austin B, Austin DA (1987) Aerobic Gram-positive rods. In: Laird LM (ed) Bacterial fish pathogenes: disease in farmed and wildfish. Ellis Horwood Ltd, Chichester, p 70-87

Austin B, Embley TM, Goodfellow M (1983) Selective isolation of Renibacterium salmoninarum. FEMS Microbiol Lett 17:111-114

Bandin I, Heinen P, Brown LL, Toranzo AE (1996) Comparison of different ELISA kits for detecting Renibacterium salmoninarum. Bull Eur Ass Fish Pathol 16(1):19-22

Bandin I, Santos Y, Magariños B, Barja J, Toranzo AE (1992) The dectection of two antigenic groups among Renibacterium salmoninarum isolates. FEMS Microbiol Lett 94: $105-110$

Bell GR, Higgs DA, Traxler GS (1984) The effect of dietary ascorbate, zink, and manganese on the development of experimentally induced bacterial kidney disease in sockeye saimon (Oncorhynchus nerka). Aquaculture 76 : 293-311

Benediktsdóttir E, Helgason S, Gudmundsdóttir S (1991) Incubation time for the cultivation of Renibacterium salmoninarum from Atlantic salmon, Salmo salar L., broodfish. J Fish Dis 14:97-102

Bradford MM (1976) A rapid and sensitive method for the quantitation of microgram quantities of protein utilizing the principle of protein-dye binding. Anal Biochem 72: $248-254$

Bruno DW (1988) The relationship between auto-agglutination, cell surface hydrophobicity and virulence of the fish pathogen Renibacterium salmoninarum. FEMS Microbiol Lett 51:135-140

Dalsgaard K (1978) A study of the isolation and characterization of the saponin Quil A. Acta Vet Scand 19 (Suppl) 69:1-40

Daly JG (1989) Growth and cell surface studies of Renibacterium salmoninarum. PhD thesis, The University of Guelph

Daly JG. Stevenson RMW (1985) Charcoal agar, a new growth medium for the fish disease bacterium Renibacterium salmoninarum. Appl Environ Microbiol 50:868-871

Daly JG. Stevenson RMW (1987) Hydrophobic and haemagglutinating properties of Renibacterium salmoninarum. J Gen Microbiol 133:3575-3580

Dubreuil D, Lallier R, Jacques M (1990) Immunoelectron microscopic demonstration that Renibacterium salmoninarum is encapsulated. FEMS Microbiol Lett 66:313-316

Embley TM, Goodfellow M, Austin B (1982) A semi-defined growth medium for Renibacterium salmoninarum. FEMS Microbiol Lett 14:299-301

Evelyn TPT, Ketcheson JE, Prosperi-Porta L (1984a) Further evidence for the presence of Renibacterium salmoninarum in salmonid eggs and for the failure to reduce the intraovum infection rate in water-hardened eggs. J Fish Dis 7 : $173-182$

Evelyn TPT, Prosperi-Porta L, Ketcheson JE (1984b) The salmonid egg as a vector of the kidney disease bacterium, Renibacterium salmoninarum. In: ACUIGRUP (ed) Fish diseases, 4th COPRAQ Session. Editora ATP, Madrid, p $111-117$

Fryer JL, Sanders JE (1981) Bacterial kidney disease of salmonid fish. Annu Rev Microbiol 35:273-298

Getchell RG, Rohovec JS, Fryer JL (1985) Comparison of Renibacterium salmoninarum isolates by antigenic analysis. Fish Pathol 20:149-159

Griffiths SG, Lynch WH (1991) Instability of the major soluble antigen produced by Renibacterium salmoninarum. J Fish Dis 14:55-66

Griffiths SG, Olivier G, Fildes J, Lynch WH (1991) Comparison of western blot, direct fluorescent antibody and dropplate culture methods for the detection of Renibacterium salmoninarum in Atlantic salmon (Salmo salar L.). Aquaculture 97:117-129

Gudmundsdóttir S, Benediktsdóttir E, Helgason S (1993) Detection of Renibacterium salmoninarum in salmonid kidney samples: a comparison of results using doublesandwich ELISA and isolation on selective medium. J Fish Dis 16:185-195

Hanatani M, Nishifuji K, Futai M, Tsuchiya T (1984) Solubilization and reconstitution of membrane proteins of Escherichia coli using alkanoyl-N-methylglucamides. J Biochem 95:1349-1353

Hildreth JEK (1982) N-D-Gluco-N-methylalkanamide compounds, a new class of non-ionic detergents for membrane biochemistry. Biochem J 207:363-366

Hsu H, Bowser PR, Schachte JH (1991) Development and evaluation of a monoclonal-antibody-based enzyme-linked immunosorbent assay for the diagnosis of Renibacterium salmoninarum infection. J Aquat Anim Health 3:168-175

Jansson E, Hongslo T, Lindberg R, Ljungberg O, Svensson BM (1991) Detection of Renibacterium salmoninarum and Yersinia ruckeri by the peroxidase-antiperoxidase immunohistochemical technique in melanin-containing cells of fish tissues. J Fish Dis 14:689-692

Lövgren K, Lindmark J, Pipkorn R, Morein B (1987) Antigenic presentation of small molecules and peptides conjugated to a preformed iscom as carrier. J Immunol Methods 98: $137-143$ 
Mattsson JG, Gersdorf H, Jansson E, Hongslo T, Göbel UB, Johansson K (1993) Rapid identification of Renibacterium salmoninarum using an oligonucleotide probe complementary to 16S rRNA. Mol Cell Probes 7:25-33

Meyers TR, Short S, Farrington C, Lipson K, Geiger HJ, Gates $R$ (1993) Comparison of the enzyme-linked immunosorbent assay (ELISA) and the fluorescent antibody test (FAT) for measuring the prevalences and levels of Renibacterium salmoninarum in wild and hatchery stocks of salmonid fishes in Alaska, USA. Dis Aquat Org 16:181-189

Morein B, Sundquist B, Höglund S, Dalsgaard K, Osterhaus A (1984) Iscom, a novel structure for antigenic presentation of membrane proteins from enveloped viruses. Nature 308:457-460

Olea I, Bruno DW, Hastings TS (1993) Detection of Renibacterium salmoninarum in naturally infected Atlantic salmon, Salmo salar L., and rainbow trout, Oncorhynchus mykiss (Walbaum) using an enzyme-linked immunosorbent assay. Aquaculture 116:99-110

Pascho RJ, Elliott DG, Mallett RW, Mulcahy D (1987) Com-

Responsible Subject Editor: T. Evelyn, Nanaimo, British Columbia, Canada parison of five techniques for the detection of Renibacterium salmoninarum in adult coho salmon. Trans Am Fish Soc 116:882-890

Rockey DD, Gilkey LL, Wiens GD, Kaattari SL (1991) Monoclonal antibody-based analysis of the Renibacterium salmoninarum p57 protein in spawning chinook and coho salmon. J Aquat Anim Health 3:23-30

Stackebrandt E, Wehmeyer U, Nader H, Fiedler F (1988) Phylogenic relationship of the fish pathogenic Renibacterium salmoninarum to Arthrobacter, Micrococcus and related taxa. FEMS Microbiol Lett 50:117-120

Sundquist B, Lövgren K, Morein B (1988) Influenza virus iscoms: antibody response in animals. Vaccine 6:49-53

Turaga PSD, Wiens GD, Kaattari SL (1987) Analysis of Renibacterium salmoninarum antigen production in situ. Fish Pathol 22:209-214

Young CL, Chapman GB (1978) Ultrastructural aspects of the causative agent and renal histopathology of bacterial kidney disease in brook trout (Salvelinus fontalis). J Fish Res Bd Can 35:1234-1248

Manuscript first received: March 8, 1995

Revised version accepted: August 11, 1996 